\title{
PHOTOGRAPHIC, RADIOGRAPHIC, AND MICROSCOPIC ASSESSMENT OF DENTAL IMPLANTS AFTER SIMULATED HEATING, BURIAL, AND IMMERSION IN WATER
}

\author{
Carolina de Souza Bonetti', Ana Carolina Taveira Bachur', Fernanda de C. P. Pires-de-Souza², Christiano de Oliveira-Santos', \\ Ricardo Henrique A. da Silva' \\ 'Department of Stomatology, Public Health and Forensic Odontology, School of Dentistry of Ribeirão Preto - University of São Paulo, Ribeirão Preto, \\ São Paulo, Brazil \\ ${ }^{2}$ Department of Dental Materials and Prosthodontics, School of Dentistry of Ribeirão Preto - University of São Paulo, Ribeirão Preto, São Paulo, Brazil
}

\begin{abstract}
INTRODUCTION: In complex cases of human identification, such as those with charred, putrefied, and mutilated cadavers as well as teeth, dental materials, and implants, play an essential role because of their highly resistance to postmortem environmental conditions.

ОвјестіvEs: The present study aimed to analyze photographic, radiographic, and microscopic images of dental implants in three common situations in forensic practice: heating, burial, and water immersion.

MATERIAL AND METHODS: Twenty-seven dental implants were installed into nine pig ribs that were sectioned into three fragments and divided into three groups. Each group underwent a different simulation process: heating at $200^{\circ} \mathrm{C}, 400^{\circ} \mathrm{C}$, and $600^{\circ} \mathrm{C}$ for 30 minutes; burial for 30,60 , and 90 days; and immersion in water for 30,60 , and 90 days. Before and after simulation, the specimens were analyzed via photographs, periapical radiographs, and scanning electron microscopy for comparison purposes.

Results: The results demonstrate that there was no significant damage in the dental implant's structure. On the other hand, the surrounding bone was affected in all groups. Detachment of the implant from the bone was observed in the samples, except in those least exposed to water submersion and heat.

ConcLusions: This study confirms the high resistance of dental implants to environmental changes that are commonly found in the forensic practice.
\end{abstract}

KEY WORDs: dental implants, forensic anthropology, dental radiography, scanning electron microscopy.

J Stoma 2020; 73, 3: 118-122

DOI: https://doi.org/10.5114/jos.2020.96875

\section{INTRODUCTION}

Forensic odontology is a field of expertise that includes the analysis of events that require technical knowledge of dentistry to support the needs of justice [1]. In practice, forensic odontologists work with expertise in the living and the deceased. In the former, the analysis of bodily injuries and age estimation exemplify some of the activities of forensic dentists, while the latter is more often illustrated by the human identification process. For human identification, forensic odontology is especially important because
JOURNAL OF STOMATOLOGY CZASOPISMO STOMATOLOGICZNE
Address for Correspondence: Dr. Ricardo Henrique Alves da Silva, Department of Stomatology, Public Health and Forensic Odontology, School of Dentistry of Ribeirão Preto - University of São Paulo, Ribeirão Preto, São Paulo, Av Café s/n, 14040-904, Ribeirão Preto, Brazil, e-mail: ricardohenrique@usp.br

ReCEIVED: 15.04.2020 • ACCEPTED: 04.06.2020 • Published: 30.06 .2020 
human teeth, dental materials, and appliances used for oral rehabilitation are highly resistant to postmortem environmental conditions, such as high temperature [2-4].

In particular, dental implants represent a strong structure that is gradually growing in the prevalence in several populations worldwide. The popularity of dental implants is especially evident in countries with increasing life expectation. In Brazil, population's mean life expectation reaches 75.8 years [5]. Oral rehabilitation with implants is more common among those aged between 40 and 49 years (29.63\%). Other prevalence rates report females $(65.75 \%)$ with a higher prevalence of dental implants compared to males [6]. In forensic odontology, dental implants and the inherent imaginological records necessary for implant surgical installation may be valuable sources of antemortem evidences. Berketa et al. [7] reported that implants not only resist to high temperatures, but also may preserve their serial numbers.

\section{OBJECTIVES}

Despite the evident contributions of dental implants to human identification, superficial information is known about the behavior of these structures when tested in simulated conditions commonly found in the forensic field. This study aimed to perform a radiographic and microscopic analysis of dental implants before and after exposure to heating, burial, and immersion in water.

\section{MATERIAL AND METHODS}

Twenty-seven dental implants were installed in nine swine [8] ribs. The implants selected were cylindrical, with $3.5 \mathrm{~mm} \times 15 \mathrm{~mm}$ in size. The implants were composed of pure titanium (grade 4), and the surface treatment was machined and acid-etched. The ribs were fragmented and distributed into three groups $(n=9)$. Digital photographs, digital radiographs, and scanning electron microscopy images were taken from the samples to simulate antemortem data. Radiographs were obtained with the same X-ray unit (Spectro 70×, Dabi Atlante, Ribeirão Preto, Brazil) with standardized parameters $(70 \mathrm{kVp}, 7 \mathrm{~mA}$, exposure time $0.2 \mathrm{~s}$, focus-to-receptor distance $20 \mathrm{~cm}$ ), using photostimulable phosphors (PSP) plates (VistaScan Perio, Durr Dental, Bietigheim-Bissingen, Germany) with resolution of $1070 \mathrm{DPI}(20 \mathrm{LP} / \mathrm{mm})$. PSP plates were centered in an acrylic device to standardize the distance and the location of position indicated by the X-ray.

After the image records, each group underwent different simulations corresponding to the forensic routine. Heating was the first simulation, in which the samples were kept in an EDG 10P-S oven (EDG Equip. Contr. Ltda., São Carlos, Brazil) at $200^{\circ} \mathrm{C}$ (subgroup A), $400^{\circ} \mathrm{C}$ (subgroup B), and $600^{\circ} \mathrm{C}[9,10]$ (subgroup $\mathrm{C}$ ), for 30 minutes. Burial was simulated by storing the samples in a nylon bag one meter under the soil. In the third simulation, the samples were stored in small bag under water in a lake. Photographs, periapical radiographs, and scanning electron microscopy images were taken after heating, burial, and immersion to produce simulated postmortem data, following the same parameters of the initial image acquisitions.

Photographic and microscopic analyses were performed qualitatively. The digital radiographs were subjectively analyzed regarding the presence of radiolucent defects in the bone/implant interface. Additionally, an objective analysis was carried out to assess the differences in bone and implant densities between radiographs taken before and after exposure to conditions. Radiographs were exported in tiff format (16-bit) and analyzed in ImageJ software (NIH, Bethesda, Maryland, USA). Regions of interest (ROI) were selected (Figure 1) in the bone adjacent to the implant $(1.5 \mathrm{~mm} \times 1.5 \mathrm{~mm}$ boxes, with their upper limits adjacent to the ninth screw of the implant, on the right side), and at the center of the implant (1.5 $\mathrm{mm} \times 1.5 \mathrm{~mm}$ boxes). Averages and standard deviations of the pixel values (grey scale) were obtained, and their heterogeneity values were further calculation (i.e. coefficient of pixel value variation in the areas of interest) [11], before and after exposure to heating, burial, and immersion. Paired $t$-test was carried out to compare the values detected in radiographs. Statistical significance was set at 5\%.

\section{RESULTS}

The photographic analysis of implants in a simulation of postmortem phase did not reveal any macroscopic

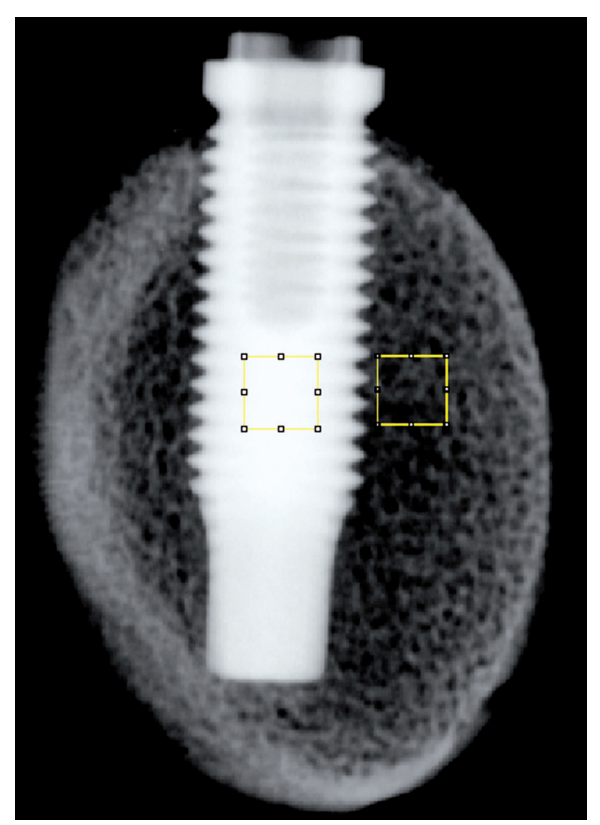

FIGURE 1. $1.5 \mathrm{~mm} \times 1.5 \mathrm{~mm}$ ROls selected in the bone adjacent to the implant and at the center of the implant. The upper limits of the regions of interest (ROls) were at the level of the ninth screw of the implants 
TABLE 1. Quantification of radiolucent defects in implants after simulated heating, burial, and immersion in water

\begin{tabular}{|l|c|c|c|c|c|c|c|c|}
\hline Simulation & $\mathbf{3 0}$ days & $\mathbf{6 0}$ days & $\mathbf{9 0}$ days & $\mathbf{2 0 0 ^ { \circ } \mathrm { C }}$ & $\mathbf{4 0 0 ^ { \circ } \mathrm { C }}$ & $\mathbf{6 0 0}{ }^{\circ} \mathrm{C}$ & \multicolumn{2}{c|}{ Total } \\
\hline Heating & $\mathrm{n} / \mathrm{a}$ & $\mathrm{n} / \mathrm{a}$ & $\mathrm{n} / \mathrm{a}$ & 1 & 4 & 6 & 11 \\
\hline Burial & 0 & 2 & 1 & $\mathrm{n} / \mathrm{a}$ & $\mathrm{n} / \mathrm{a}$ & $\mathrm{n} / \mathrm{a}$ & 3 \\
\hline Immersion & 2 & 2 & 4 & $\mathrm{n} / \mathrm{a}$ & $\mathrm{n} / \mathrm{a}$ & $\mathrm{n} / \mathrm{a}$ & 8 \\
\hline
\end{tabular}

n/a-not applicable

A
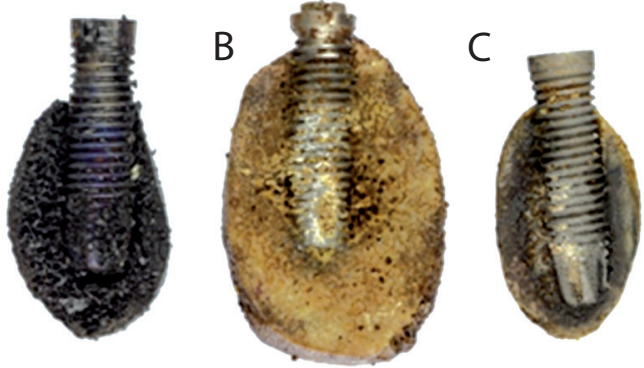

FIGURE 2. Photographic images obtained after submission to each forensic condition

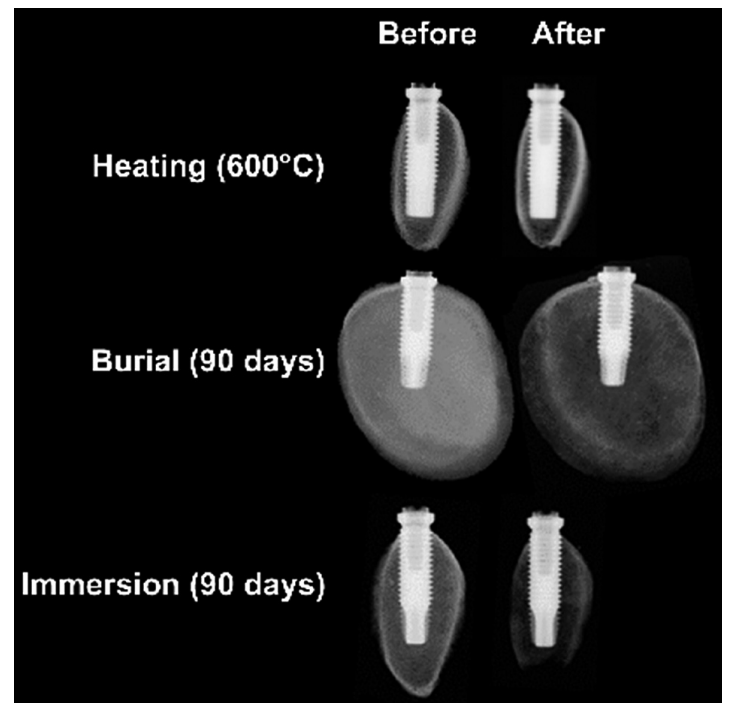

FIGURE 3. Radiographs of heat $\left(600^{\circ} \mathrm{C}\right)$, water (90 days), and land (90 days) samples, before and after exposure

TABLE 2. Mean pixel values of bone and heterogeneity of the region of interest (ROI) before and after exposure to heating, burial, and immersion in water

\begin{tabular}{|c|c|c|c|c|}
\hline Simulation & Before & After & Variation & $p$-value \\
\hline \multicolumn{5}{|l|}{ Heating } \\
\hline Pixel value & 26834 & 17305 & $-35.5 \%$ & \multirow[t]{2}{*}{$0.003^{*}$} \\
\hline Heterogeneity & $13.3 \%$ & $32.8 \%$ & $147.5 \%$ & \\
\hline \multicolumn{5}{|l|}{ Burial } \\
\hline Pixel value & 27,547 & 20,941 & $-24.0 \%$ & \multirow[t]{2}{*}{$0.04^{*}$} \\
\hline Heterogeneity & $8.1 \%$ & $16.6 \%$ & $103.3 \%$ & \\
\hline \multicolumn{5}{|l|}{ Immersion } \\
\hline Pixel value & 19,869 & 14,106 & $-29.0 \%$ & \multirow[t]{2}{*}{0.09} \\
\hline Heterogeneity & $12.3 \%$ & $24.5 \%$ & $99.2 \%$ & \\
\hline
\end{tabular}

alteration after maximum heating $\left(600^{\circ} \mathrm{C}\right)$ and maximum stay under the soil and water (90 days). The only evident sign of heating, burial, and immersion in water was the change of color spectrum to dark (after heating), brownish (after burial), and opaque grayish (after immersion in water) (Figure 2).

In the radiographic analysis (Figure 3), radiolucent defects were more prevalent in implants that underwent heating $\left(n=1\right.$ at $200^{\circ} \mathrm{C}, n=4$ at $400^{\circ} \mathrm{C}$, and $n=6$ at $600^{\circ} \mathrm{C}$ ) and less prevalent in implants that were buried ( $n=0$ at 30 days, $n=2$ at 60 days, and $n=1$ at 90 days) (Table 1). The radiolucent defects were visible in the interface between implant and bone.

When a bone was specifically analyzed from radiographs, a decrease in bone density and an increase in the heterogeneity of the region of interest (ROI) was observed. Bone density differences before and after simulations were statistically significant for samples that underwent heating and burial (Table 2).

Through scanning using electron microscopy (magnification of $20 \times$ ), the qualitative analysis showed differences that were more evident between samples, which underwent heating and immersion. In the former, bone porosity was clearly visible, and the implant was apparently undamaged (Figure 4), while in the latter, a mass covering the implant surface and the adjacent bone was detected (Figure 5).

\section{DISCUSSION}

Science behind dental human identification evolved to a point where a simulation of forensic conditions became possible to understand the behavior of teeth and dental materials under adverse environmental conditions to predict and support performances in practice. Charred and putrefied bodies are commonly found as a result of heating, burial, or immersion in water. This study aimed to investigate the behavior of dental implants and adjacent bone after exposure to simulated heating, burial, and immersion in water conditions via photographic, radiographic, and microscopic analyses.

Heating was the first simulation, with a temperature ranged from $200^{\circ} \mathrm{C}$ to $600^{\circ} \mathrm{C}$. As expected, macroscopic changes in the implant itself were not detected, since dental implants are extremely resistant to high temperature because of a titanium oxide layer covering, which provides a high melting point $\left(1,650^{\circ} \mathrm{C}\right)$ to the metallic structure [7, 12-14]. However, it is important to note that 
at nearly $400^{\circ} \mathrm{C}$, implants may detach after structural alterations in the surrounding bone. This phenomenon is especially relevant in crime scene investigations [15] because implants may be outside the oral cavity and even far from the cadaver. Unnoticed implants may impede human identification, with discrepancies in antemortem and postmortem data.

When it comes to antemortem and postmortem data, radiographic records are fundamental to support the process of human identification with more dental information and evidences [16]. Periapical radiographs were chosen in this study because they consist of an image modality commonly used in the routine of medico-legal institutes. In practice, periapical radiographs are often taken with handheld portable devices, especially in mass disasters. When the dental implants that underwent heating were analyzed through periapical radiographs, a higher prevalence of radiolucent defects was observed. The defects were more predominant in the interface between implant and bone. A reasonable explanation for this finding is the combination of high temperature and low-humidity environment, which contribute to implant mass loss. These outcomes were confirmed when bone density was investigated. Differences before and after heating reached statistically significant values $(p=0.003)$ and showed a decrease in bone density.

In the group that underwent simulated burial, the changes were similar. Macroscopically, the interface between the implant and bone was affected, and the implant moved outside the bone. Despite moving, forensic dentists must be aware of the implant marks abandoned in the bone. In practice, microscopic analysis may be performed to confirm that an implant was installed in the bone and was lost peri- or postmortem. Other evidence that may be analyzed from the buried samples is the soil traces that are found in the bone. Soil temperature and humidity [17] may be assessed in the forensic routine to enabled inferences about the location in which the body was found. Bone density also changed after burial $(p=0.04)$ denoting a mineral loss. Because of the eventual implant loss that may occur after burial, forensic dentists must be aware of proper excavation techniques for field expertise in anthropology, in which mass/clandestine graves must be searched in detail for human remains and (potentially) detached dental implants.

After the simulation of immersion in water, evident changes were not detected in the implants and bone, as previously detected in heating and burial conditions. However, it must be noted that the implants presented sediments and an opaque grayish color that may represent signs of corrosion [18]. Studies show that $\mathrm{pH}$ and the presence of chlorides might influence a dental implant corrosion, because they are capable of breaking the titanium oxide layer that covers the implant surface and are responsible for reducing its reactivity $[13,14$, 19-21]. Not only external conditions but the implant's metallic alloy and the surface treatment can also influ-

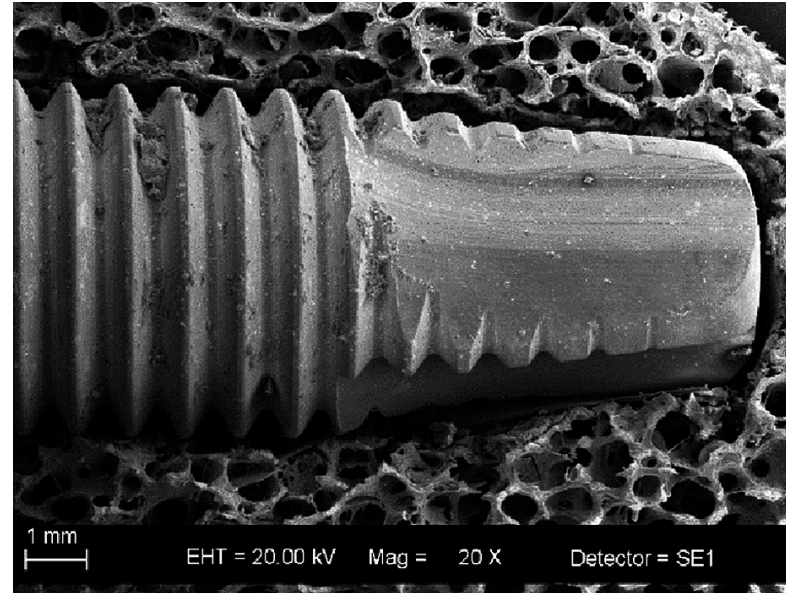

FIGURE 4. Scanning electron microscopy of the implant's apical region and surrounding bone (20x magnification): $400^{\circ} \mathrm{C}$ heat sample

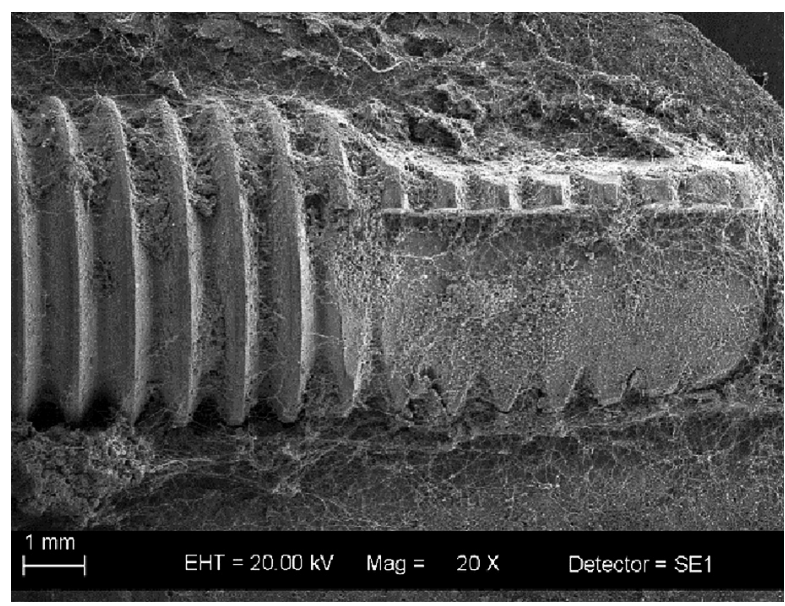

FIGURE 5. Scanning electron microscopy of the implant's apical region and surrounding bone (20x magnification): 30 days immersion sample

ence the corrosive process. Zirconium alloys present lower corrosion rates against pure commercial titanium [22]. Regarding the surface treatment, studies reported a lower corrosion rate using acid etching, when compared to sandblasting and machined implants without acid etching $[22,23]$. Corrosion is an important phenomenon because it compromises the interface between the implant and bone. The present study confirms this finding because the implants were easily removed from the bone, especially after 90 days under water.

This study designed three simulated conditions that are compatible with the forensic routine of violent deaths. Future studies in this field are encouraged to investigate even more realistic simulations by using soft tissue around to protect the bone and implant, as it occurs in practice. Furthermore, in this research, the implants were screwed into the bone and the osseointegration process did not occur, which can influence the analyses of 
the detachment of material and the defects in boneimplant interface. Whenever feasible, osseointegrated implants should be used, e.g. by sampling research pigs that underwent previous investigations in the field of implantology and that are scheduled for euthanasia.

\section{CONCLUSIONS}

Under the circumstances of the present study, dental implants presented high resistance to heating up to $600^{\circ} \mathrm{C}$, and to burial and immersion in water up to 90 days. On the other hand, the surrounding bone presented radiographic and microscopic alterations that are relevant for human identification in forensic odontology.

\section{ACKNOWLEDGMENTS}

The authors gratefully acknowledge Dabi Atlante ${ }^{\varpi}$, which supplied the dental implants for the research; the Scanning Electron Microscopy Laboratory at USP, the Faculty of Philosophy, Sciences, and Letters of Ribeirão Preto, specifically the Department of Chemistry, for lending their SEM; and FAPESP, the São Paulo Research Foundation for the financial support (process, 2015/201502-0).

\section{CONFLICT OF INTEREST}

The authors declare no potential conflicts of interest with respect to the research, authorship, and/or publication of this article.

\section{References}

1. Coutinho CGV, Ferreira CA, Queiroz LR, Gomes LO, da Silva UA. O papel do odontolegista nas perícias criminais. Revista da Faculdade de Odontologia 2013; 18: 217-223.

2. Bush M, Miller R. The crash of Colgan Air flight 3407: advanced techniques in victim identification. J Am Dent Assoc 2011; 142: 1352-1356.

3. Hughes CE, White CA. Crack propagation in teeth: a comparison of perimortem and postmortem behavior of dental materials and cracks. J Forensic Sci 2009; 54: 263-266.

4. De Angelis D, Cattaneo C. Implant bone integration importance in forensic identification. J Forensic Sci 2015; 60: 505-508.

5. Instituto Brasileiro de Geografia e Estatística - IBGE. Tábua completa de mortalidade para o Brasil. Breve análise da evolução da mortalidade no Brasil; 2016. Available at: https://www.ibge.gov.br/ estatisticas/sociais/populacao/9126-tabuas-completas-de-mortalidade.html?edicao=18460\&t=resultados (Accessed: 16.05.2016).

6. Ortega-Lopes R, Nóia CF, Andrade VC, Cidade CPV, Mazzonetto R. Perfil dos pacientes tratados com implantes dentários: análise retrospectiva de sete anos. Revista Portuguesa de Estomatologia, Medicina Dentária e Cirurgia Maxilofacial 2011; 52: 147-152.

7. Berketa J, Marino V, James H. Survival of batch numbers within dental implants following incineration as an aid to identification. J Forensic Odontostomatol 2010; 28: 1-4.

8. Pearce AI, Richards RG, Milz S, Schneider E, Pearce SG. Animal models for implant biomaterial research in bone: a review. Eur Cell Mater 2007; 13: 1-10.
9. Paiva LAS. Patologia forense nas mortes com evidente ação do fogo. Saúde, Ética \& Justiça 2006; 11: 1-7.

10. Richards N. Fire investigation-destruction of corpses. Med Sci Law 1977; 17: 79-82.

11. Crusoé-Rebello I, Oliveira C, Campos PS, Azevedo RA, dos Santos JN. Assessment of computerized tomography density patterns of ameloblastomas and keratocystic odontogenic tumors. Oral Surg Oral Med Oral Pathol Oral Radiol Endod 2009; 108: 604-608.

12. Berketa J, Marino V, James H. Dental implant changes following incineration. Forensic Sci Int 2011; 207: 50-54.

13. Chaturvedi TP. An overview of the corrosion aspect of dental implants (titanium and its alloys). Indian J Dent Res 2009; 20: 91-98.

14. Olmedo DG, Duffo G, Cabrini RL, Guglielmotti MB. Local effect of titanium implant corrosion: an experimental study in rats. Int J Oral Maxillofac Surg 2008; 37: 1032-1038.

15. Berketa J, James H, Marino V. A pilot study in the recovery and recognition of non-osseointegrated dental implants following cremation. J Forensic Odontostomatol 2011; 29: 38-44.

16. Berketa JW, Hirsch RS, Higgins D, James H. Radiographic recognition of dental implants as an aid identifying the deceased. J Forensic Sci 2010; 55: 66-70.

17. Delannoy Y, Colard T, Le Garff E, et al. Effects of the environment on bone mass: a human taphonomic study. Leg Med (Tokyo) 2016; 20: 61-67.

18. Harada R, Takemoto S, Kinoshita H, Yoshinari M, Kawada E. Influence of sulfide concentration on the corrosion behavior of titanium in a simulated oral environment. Mater Sci Eng C Biomim Mater Sens Syst 2016; 62: 268-273.

19. Shah R, Penmetsa DSL, Thomas R, Mehta DS. Titanium corrosion: implications for dental implants. Eur J Prosthodont Restor Dent 2016; 24: 171-180.

20. Shemtov-Yona K, Rittel D, Levin L, Machtei EE. The effect of orallike environment on dental implants' fatigue performance. Clin Oral Implants Res 2014; 25: 166-170.

21. Suito H, Iwawaki Y, Goto T, Tomotake Y, Ichikawa T. Oral factors affecting titanium elution and corrosion: an in vitro study using simulated body fluid. PLoS One 2013; 8: 1-7.

22. Cordeiro JM, Faverani LP, Grandini CR, et al. Characterization ofchemically treated $\mathrm{Ti}-\mathrm{Zr}$ system alloys for dental implant application. Mater Sci Eng C 2018; 92: 849-861.

23. Dehua Li, Baolin Liu, Yong Han, Kewei Xu. Effects of a modified sandblasting surface treatment on topographic and chemical properties of titanium surface. Implant Dentistry 2001; 10: 59-64. 